\title{
Prevalence of Gastrointestinal Nematodes and Associated Intrinsic Risk Factors in and Around District Peshawar, Khyber Pakhtunkhwa, Pakistan
}

\section{Sohail Khan ${ }^{1}$, Arsala Khan ${ }^{2}$, Aziz Ullah ${ }^{1 *}$, Salahud Din², Nazeer Muhammad ${ }^{3}$, Usman Ghani $^{4}$, Muhammad Zeeshan ${ }^{4}$, Hazrat Salman Sidique ${ }^{1}$, Hussain Ali ${ }^{2}$, Aminullah $^{2}$}

${ }^{1}$ Veterinary Research Institute, Peshawar, Pakistan; ${ }^{2}$ Livestock and dairy Development Department (Extension wing) Khyber Pakhtunkhwa; ${ }^{3}$ College of Veterinary Sciences, The University of Agriculture, Peshawar; ${ }^{4}$ University of Veterinary and Animal Sciences, Lahore, Pakistan.

\begin{abstract}
The study was aimed to know the prevalence of gastrointestinal nematodes of equines in district Peshawar of Khyber Pakhtunkhwa, Pakistan. A total of 150 fecal samples were randomly collected from equines including both horses and donkeys with the age ranging from 2 to 10 years in and around district Peshawar; and examined through direct microscopy and simple flotation methods. The overall prevalence of gastrointestinal nematodes was $75.4 \%$ with $80 \%$ in donkeys and $70.66 \%$ in horses. The prevalence was higher in the younger group (82.22\%) followed by 5 year old (75.38\%) and 10 years old (67.5\%), the females were more prone to nematode infection (77.77\%) than males (72.5\%). Similarly, the prevalence was higher in emaciated (88.6\%) as compared to moderate $(71.42 \%)$ and healthy equines (30.9\%). The Strongylus species were more prevalent both in horses and donkeys (20\% and 26\%) in Peshawar followed by Parascaris equorum (14\%), Oxyuris equi was $10 \%$ in horses and $4 \%$ in donkeys while, the prevalence of Strongyloides westeri was $6 \%$, about $18 \%$ of the horses were infected by mix species, while in donkeys mix infection was $28 \%$. It is concluded that the prevalence of gastrointestinal nematodes was quite high both in horses and donkeys in and around district Peshawar, Khyber Pakhtunkhwa. Hence to utilize horses and donkeys more efficiently in the respective area, further control measures against gastrointestinal nematodes and other parasites as well must be necessary.
\end{abstract}

Keywords | Prevalence, Gastrointestinal nematodes, intrinsic risk factors, Peshawar.

Editor | Muhammad Imran Rashid, Department of Parasitology, University of Veterinary and Animal Sciences, Lahore, Pakistan.

Received | June 26, 2019; Accepted | December 18, 2019; Published | March 30, 2020

*Correspondence | Aziz Ullah, Veterinary Research Institute, Peshawar, Pakistan; Email: azizhassankhan@gmail.com

Citation | Khan S, Khan A, Ullah A, Din S, Muhammad N, Ghani U, Zeeshan M, Sidique HS, Ali H, Aminullah (2020). Prevalence of gastrointestinal nematodes and associated intrinsic risk factors in and around district peshawar, khyber pakhtunkhwa, pakistan .J. Adv. Parasitol. 7(1): 1-6.

DOI | http://dx.doi.org/10.17582/journal.jap/2020/7.1.1.6

Copyright $(2020$ Ullah et al. This is an open access article distributed under the Creative Commons Attribution License, which permits unrestricted use, distribution, and reproduction in any medium, provided the original work is properly cited.

\section{INTRODUCTION}

$\mathrm{T}$ he world is home to about 22.4 million equines that include 35\% horses, 33\% donkeys, 20\% zebras and $12 \%$ mule (Abayneh et al., 2002). In areas with underdeveloped infrastructures including Pakistan, equines are used as a major substitute for transportation and play a significant rule in agriculture and industrial sectors (Feseha et al., 1991; Mezgebu et al., 2013). Donkeys are mainly used in underdeveloped countries as draught and pack animals. In villages of hilly areas, donkeys are used for cart purpose and as a saddle animal (Uslu and Guclu, 2007). In Pakistan, the equines population is about 6 million including 5.1 million asses, 0.2 million mules and 0.4 million horses (Wasti et al., 2018-19). Gastrointestinal parasitism is one of the major problems in equines that decreased the population of equines due to high morbidity, mortality rates; the cost of prevention and treatment (Rashid et al., 2016). Equines are infected with a broad range of gastrointestinal parasites, among them nematodes are usually known as roundworms are most important (Love et al., 1999; Mahboob et al., 2008). They cause huge losses to equine population in term of decreased feed intake and anorexia, as well as blood plasma protein loss into the gastrointestinal tract, changes in protein metabolism, and low activity of minerals action, causes 
diarrhoea and decreases intestinal enzymes (Radostits et al., 2000). Thus parasitic infection has proven to be one of the major issues against the successful raising of equines in the world (Ali et al., 2018), gastrointestinal helminthiasis is a major challenge to grazing animals throughout the globe including Pakistan (Goraya et al., 2013; Tahir et al., 2016) Several studies regarding prevalence of gastrointestinal helminths through fecal examination by direct microscopy, flotation and sedimintation techniques revealed high prevalence rate of gastrointestinal nematodes in both horses and donkeys (Mezgebu et al., 2013). In Pakistan a number of studies have been conducted regarding prevalence of gastrointestinal nematodes in equines of various parts of the country including both urban and semi urban areas (Goraya et al., 2013). Keeping in view the scanty information regarding prevalence of gastrointestinal nematodes in equine population in and around of district $\mathrm{Pe}-$ shawar, Khyber Pakhtunkhwa, Pakistan, the present study was designed to study the prevalence rate and associated risk factors of these nematodes which will provide baseline data for their effective control.

\section{MATERIALS AND METHODS}

\section{Study Area}

The current survey was conducted in and around district Peshawar of Khyber Pakhtunkhwa, Pakistan.

\section{Source of Equines}

In order to study the prevalence rate and associated intrinsic risk factors of gastrointestinal nematodes in equine population, both horses and donkeys with age ranging from 2 to 10 years, having different body conditions, i.e. thin and emaciated; moderate and healthy including both male and female were selected. A total of 150 equines including 75 horses (45 Male and 30 Female) and 75 donkeys (45 Male and 30 Female) were examined in the present study.

\section{Collection of Fecal Sample}

About 20gm fecal samples were directly collected from the rectum of equines, premedicated at different intervals, and placed in small polythene zip bags and marked with information regarding age, sex, and body condition of the animal. A total of 150 fecal samples were collected; all the samples were stored at $-5{ }^{\circ} \mathrm{C}$ until further processing. All the samples collected from the field were transported in the cold chain to the Parasitology lab in the University of Veterinary and Animal Sciences, Lahore, Pakistan.

\section{Examination of Fecal Sample}

Each and every fecal sample was microscopically examined using direct smear method and flotation method. For the purpose of flotation method $5 \mathrm{gm}$ of fecal sample was transferred to a beaker and $30 \mathrm{ml}$ flotation solution (satu- rated Nacl solution) was added. The mixture was stirred through a glass stick until the mixture became homogenous, it was then filtered through a standard sieve with $0.18 \mathrm{~mm}$ mesh and the filtrate was poured in a test tube and kept in tube rack, more flotation solution was added until formation of meniscus, then a clean glass coverslip was applied on meniscus and kept undisturbed for 10-15 minutes, the coverslip was then removed, kept on a clean glass slide and examined under the microscope (Zajac and Conboy, 2012). The eggs and larvae of nematodes species found in positive fecal samples were identified on the basis of their morphological characteristics using the standard key as described (Soulsby, 1984).

\section{Statistical Analysis}

The data regarding the prevalence of GI nematodes were analyzed using SPSS for the windows version 20. The prevalence of nematode infection was expressed in percentages. The chi-square test was used to check any statistical association in the prevalence of gastrointestinal nematodes with each variable, i.e. age, sex and health status of equine. Various groups were considered statistically significant at $\mathrm{P}<0.05$.

\section{RESULTS}

The results of the current survey revealed that the overall prevalence of gastrointestinal nematodes was $75.3 \%$ in equines. The nematode parasites were more prevalent in female $(77.77 \%)$ than male $(72.5 \%)$ equine species (Table 1 ). In the present study, $80 \%$ donkeys were infected with gastrointestinal nematodes, while in horses the prevalence of gastrointestinal nematodes noted was 70\% (Table 1). Data perceived regarding prevalence on the basis of equines age shows that the nematodes were more prevalent in young (82.22\%) followed by 5 year old (75.38\%) and 10 year old equines (67.5\%), indicating no significant difference in the prevalence of gastrointestinal nematodes in different age groups of equines. The prevalence of nematodes was high in emaciated (88.6\%) as compared to moderate (71.42\%) and healthy equines (59.2\%). There was a significant association between the prevalence of nematodes and body condition. Data regarding the prevalence of various species of nematodes showed that in horses and donkeys of district Peshawar Strongylus species were more prevalent $(20 \%$ and $26 \%$ respectively) followed by Parascaris equorum $14 \%$ both in donkeys and horses. Oxyuris equi was $10 \%$ in horses and $4 \%$ in donkeys, Strongyloides westeri was $6 \%$ both in horses and donkeys, about $18 \%$ of the horses were infected by mix species, while in donkeys mix infection was $28 \%$ (Figure $1)$. 
Table 1: Prevalence of gastrointestinal nematodes, on the basis of various parameters, in equine population in and around District Peshawar, Khyber Pakhtunkhwa.

\begin{tabular}{|c|c|c|c|c|c|}
\hline & & \multicolumn{2}{|c|}{ Gastrointestinal nematodes } & \multirow[t]{2}{*}{ Total } & \multirow{2}{*}{$p$-value } \\
\hline & & Positive (\%) & Negative (\%) & & \\
\hline \multirow[t]{2}{*}{ Species } & Horses & $53(70.66 \%)$ & $22(29.33 \%)$ & 75 & \multirow[t]{2}{*}{0.185} \\
\hline & Donkey & $60(80 \%)$ & $15(20 \%)$ & 75 & \\
\hline \multirow[t]{2}{*}{ Sex } & Females & $70(77.77 \%)$ & $20(22.33 \%)$ & 90 & \multirow[t]{2}{*}{0.395} \\
\hline & Males & $43(72.5 \%)$ & $17(27.5 \%)$ & 60 & \\
\hline \multirow[t]{3}{*}{ Body Condition } & Emaciated & $47(88.6 \%)$ & $6(9.52 \%)$ & 53 & \multirow[t]{3}{*}{0.000} \\
\hline & Moderate & $50(71.42 \%)$ & $20(28.5 \%)$ & 70 & \\
\hline & Healthy & $16(59.2 \%)$ & $11(40.7 \%)$ & 27 & \\
\hline \multirow[t]{3}{*}{ Age } & 2 years & $37(82.22 \%)$ & $8(17.77 \%)$ & 45 & \multirow[t]{3}{*}{0.291} \\
\hline & 5 years & $49(75.38 \%)$ & $16(24.61 \%)$ & 65 & \\
\hline & 10 years & $27(67.5 \%)$ & $13(32.5 \%)$ & 40 & \\
\hline
\end{tabular}

2 years $=$ Young

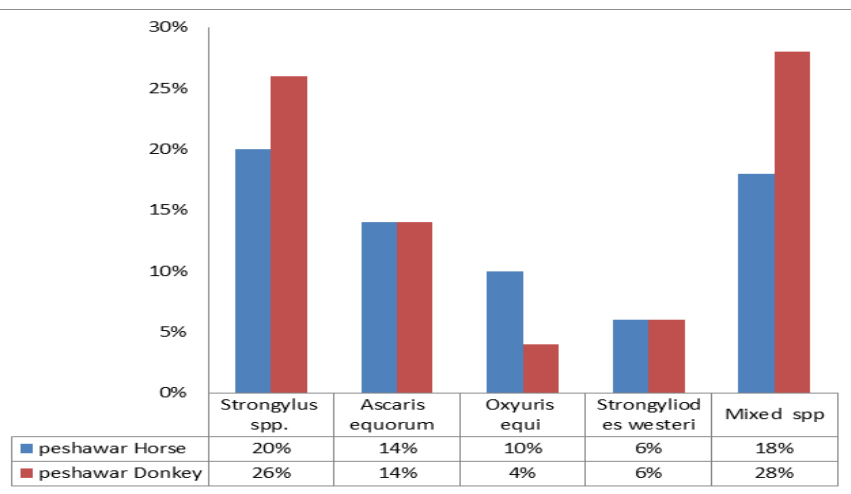

Figure 1: Prevalence of various species of gastrointestinal nematodes in equine of district Peshawar.

\section{DISCUSSION}

Equines are the final host of many helminths species and these adversely affect the health status of equines in the form of poor body condition, reduced power output, poor reproductive performance, retarded growth and short lifespan of equines and therefore creating one of the major barriers in the successful rearing of these animals. In Pakistan, many studies are undertaken in different agroclimatic regions of the country regarding prevalence and control of gastrointestinal parasitism in equines (Goraya et al., 2013a; Goraya et al., 2013b; Tahir et al., 2016). In different agroclimatic conditions, due to varied management and parasite control, the prevalence of equines helminthiasis varies considerably from country to country, which may be attributed to the underlying different practices around the world (Chapman et al., 2002; Montenaro et al., 2002; Boxell et al., 2004; Capewell et al., 2005). For instance, the worldwide prevalence of gastrointestinal tract (GIT) helminthiasis in horses ranged from $12.4 \%$ in France to 100\% in Romania (Morariu et al., 2012).
The overall prevalence of gastrointestinal nematodes in the current study in district Peshawar in equine population was $75 \%$ which shows consistency with the data previously perceived by (Tesfu et al., 2014; Ali et al., 2018; Regassa and Yimer, 2013). They reported $72.7 \%$ prevalence of gastrointestinal nematodes parasite at Hawassa town in Ethiopia, Bajaur and Mohmand agencies, north-west Pakistan, and in South wollo zone, respectively. But, the observations of the current study was relatively lower than reports of (Mezgebu et al., 2013; Ibrahim et al., 2011; Ayele and Dinka, 2010), with their respective results of $92.71 \%$, $96.9 \%$ and $98.2 \%$ for GIT helminths parasite infection of equine around Gondar, Hawassa Town and Dugda Bora District respectively. However, in the current study, the prevalence was $80 \%$ in donkeys and $70 \%$ in horses. In contrast to the current study, a lower prevalence of $(55.66 \%)$ reported in donkeys of District Lahore, Pakistan (Sawsan et al., 2008), who reported a prevalence of $29.79 \%$ in horse and $37.48 \%$ in donkeys in South Darfur state, Sudan. These differences in the prevalence of gastrointestinal nematodes in equines may be due to the difference in the study area, nutritional status of animals in the respective area of study, different geographical locations, which can influence the level of immunity of host equine species. Likewise, the low prevalence of gastrointestinal nematodes in some previous studies as compared to current study may be due to deworming strategy of equines, hygienic grazing system and accessibility to the veterinary clinic (Eydal, 1983).

The prevalence of GI nematodes in donkeys in the current investigations was higher than reported by (Ayele and Dinka, 2010) in Central Shewa, Ethiopia (Seri et al., 2004) and higher prevalence (82\%) of GI nematodes in donkeys in and around North West Ethiopia from the current study was reported by (Bogale et al., 2012). In this study, the prevalence of nematodes was more in donkeys than horses, similar to the current study, (Mezgebu et al., 2013) record- 
ed the comparably low level occurrence of gastrointestinal nematodes in horses than donkeys. Higher prevalence of GI nematodes in donkeys as compared to horses in the present study may be due to comparatively less attention given to them in the study area that is far lesser than their workload. Horses in the study area are mostly used for cart pulling and mostly dewormed and on the other hand, donkeys are given less attention.

Age, sex and body condition were measured as intrinsic risk factors for GI nematodes infection in equines. A high prevalence of gastrointestinal nematodes was observed in the young age group and female equines as compared to other groups but had no significant difference between the groups. Similar to the current study (Sheferaw and Alemu 2015; Saeed et al., 2010; Yadav et al., 2014) reported higher prevalence in young group. The study conducted by (Francisco et al., 2009) showed that the prevalence of gastrointestinal nematodes was high in young horses less than 3 years old, they also concluded that females were more parasitized than males. (Bogale et al., 2012) reported high prevalence of nematodes in female equines than male equines. The possible reason for this may be the physiological stress faced by the female equines. It incurred from the current study and from the previously reported literature that young and female equines are highly prone to nematodes infections. Therefore, it should be kept in mind during the policy making of deworming for equines. The impact of age, sex, grazing system, farm system and breed of equines on prevalence of gastrointestinal nematodes was also elaborated by (Kornas et al., 2010) in 11 years long study. The prevalence of equines nematodes in the current study revealed a significantly higher difference with respect to the body condition of equines, that is, the prevalence of nematodes was always highest among the emaciated and thinner equine species as compared to weak and healthy animals. This argument is supported by earlier reports published by (Mezgebu et al., 2013; Tesfu et al., 2014). Similarly (Mezgebu et al., 2013) also reported a statistically significant association between body condition and gastrointestinal nematodes infection.

The species wise percentage of GI nematodes reported in this study showed that the prevalence of Strongylus was $20-24 \%$ in horses and $26-32 \%$ in donkeys which was higher than the results of Alemayehu and Etaferahu, (2013). This difference may be due to great invovlement of equines in unhygenic grazing system and no or improper deworming strategy in the study area. The prevalence of Strongyloides westeri in the present study is in accordance with (Uslu and Guclu, 2007). They reported that the mean prevalence of Strongyloides westeri in horses was $7.2 \%$ while, in donkeys was 6\%. Similarly, the prevalence of Parascaris equorum recorded was $12-14 \%$ in horses which is related with the results of (Oli, 2018) while the prevalence of Parascaris equorum in donkeys (14-16\%) is in accordance with the results of (Uslu and Guclu, 2007). Oxyuris equi was 10-12\% in horses and $4-8 \%$ in donkeys that coincide with the data reported by (Mahfooz et al., 2008). (Anazi and Alyousif, 2011) also reported $8.8 \%$ prevalence of nematodes in horses in Saudi Arabia. Mixed infection observed was 18-20\% in horses and $24-28 \%$ in donkeys of district Peshawar, these results are related to that of (Wosu and Udobi, 2014; Aypak and Burgu, 2013).

It is concluded from the current study that the prevalence of gastrointestinal nematodes was quite high both in horses and donkeys in and around of district Peshawar Khyber Pakhtunkhwa, where these animals are kept for both agriculture and transportation purposes, it means that the parasitic infection especially the roundworms are not duly considered in the respective study area, in order to utilize the horses and donkeys more efficiently the protective measures against gastrointestinal nematodes and other parasites as well must be necessary. In addition to its importance in the control and management of the pathological conditions of equines in the area, this study would provide a baseline for future research in the field.

\section{ACKNOWLEDGEMENTS}

The authors are grateful to all the technical staff of the Research Laboratory of the Department of Clinical Medicine and Surgery, University of Veterinary and Animal Sciences Lahore, Pakistan for their technical support and assistance.

\section{CONFLICT OF INTEREST}

The authors declare no conflicts of interest regarding publication of this paper.

\section{AUTHORS CONTRIBUTION}

S.K., A.K. \& A.U. conceived idea of the manuscript and designed the experiment. U,G., M.Z., H.S.S., H.A. \& Aminullah conducted animal sampling. S.K. A.K. \& H.A. conducted microscopic examination of the samples. A.U., S.D. \& N.M. contributed to data analysis and interpretation as well as manuscript editing. S.K., A.K., A.U. \& H.A. drafted and wrote the manuscript. All authors reviewed the final version of the manuscript.

\section{REFERENCES}

-Abayneh T, Gebreab F, Zekarias B, Tadesse G (2002). The potential role of donkeys in land tillage in central Ethiopia. Bull. Anim. Health. Prod. Afr. 50: 172-178.

-Alemayehu R, Etaferahu Y (2013). Gastrointestinal parasites of equine in South Wollo Zone, North Eastern Ethiopia. 
Glob. Vet. 11 (6): 824-830.

-Ali H, Tauseef I, Haleem S, Ullah I, Shah A, Khattak M, Mahmood S, Khan M, Rashid A, Rehman A (2018). Prevalence of gastrointestinal nematodes in equines of bajaur and mohmand agencies, north-west pakistan. JAPS, J. Anim. Plant. Sci. 28 (3): 695-701.

-Anazi ADA, Alyousif MS (2011). Prevalence of non-strongyle gastrointestinal parasites of horses in Riyadh region of Saudi Arabia. Saudi. J. Biol. Sci. 18 (3): 299-303. https:// doi.org/10.1016/j.sjbs.2011.02.001

-Ayele G, Dinka A (2010). Study on strongyles and parascaris parasites population in working donkeys of central Shoa, Ethiopia. Livest. Res. Rural Dev. 22 (12): 145-169.

-Aypak S, Burgu A (2013). Prevalence of the stomach helminths in equines. Vet. Fak. Derg. 24 (1): 29-35.

-Bogale B, Sisay Z, Chanie M (2012). Strongyl nematode infections of donkeys and mules in and around Bahirdar, Northwest Ethiopia. Glob. Vet. 9 (4): 497-501.

-Boxell AC, Gibson KT, Hobbs RP \& Thompson RCA (2004). Occurrence of gastrointestinal parasites in horses in metropolitan Perth, Western Australia. Aust. Vet. J. 82(12): 91-95. https://doi.org/10.1111/j.1751-0813.2004. tb14653.x

- Capewell LG, Hunt D, Guerrero J, Newcomb K, Root T (2005). The prevalence of strongyles in stabled and pastured horses in Vermont and efficacy of anthelmintic programs in these horses. Intern. J. Appl. Res. Vet. Med. 3: 227-232.

- Chapman MR, French DD, Klei TR (2002). Gastrointestinal helminths of ponies in Louisiana: a comparison of species currently prevalent with those present 20 years ago. J. Parasitol. 88(6): 1130-1134. https://doi.org/10.1645/00223395(2002)088[1130:GHOPIL]2.0.CO;2

-Eydal M (1983). Gastrointestinal parasites in horses in Iceland. J. Agr. Res. Iceland. 15 (1/2): 3-28.

- Feseha G, Mohammed A, Yilma J (1991). Vermicular endoparasitism in donkeys of Debre-Zeit and Menagesha, Ethiopia: Strategic treatment with ivermectin and fenbendazole. In Donkeys, mules and horses in tropical agricultural development, D. Fielding and R. A. Pearson (eds.). Edinburgh. Cent. Trop. Vet. Med. 156-166.

- Francisco I, Arias M, Cortiñas FJ, Francisco R, Mochales E, Dacal V, Suárez JL, Uriarte J, Morrondo P, SánchezAndrade, R, Díez-Baños P, Paz-Silva A (2009) Intrinsic factors influencing the infection by helminth parasites in horses under an oceanic climate area (NW Spain).J.Parasitol. Res. 2009:616173. https://doi.org/10.1155/2009/616173

- Goraya K, Iqbal Z, Sajid MS, Muhammad G (2013). Frequency distribution of equine diseases in three metropolises of the upper Punjab, Pak. Int. J. Agric. Biol. 15 (6): 1067-1074.

- Goraya K, Iqbal Z, Sajid MS, Muhammad G, Ain QU, Saleem M (2013). Diversity of flora used for the cure of equine diseases in selected peri-urban areas of Punjab, Pakistan. J. Ethnobiol. Ethnomed. 9 (1): 70. https://doi. org/10.1186/1746-4269-9-70

-Ibrahim N, Berhanu T, Gelalcha BD, Tolosa T (2011). Survey of prevalence of helminth parasites of donkeys in and around hawassa town, Southern Ethiopia. Glob. Vet. 6 (3): 223-227.

-Kornaś S, Cabaret J, Skalska M, Nowosad B (2010). Horse infection with intestinal helminths in relation to age, sex, access to grass and farm system. Vet. Parasitol. 174 (3-4): 285-291. https://doi.org/10.1016/j.vetpar.2010.09.007

-Love S, Murphy D, Mellor D (1999). Pathogenicity of cyathostome infection. Vet. Parasitol. 85 (2-3): 113-121. https://doi.org/10.1016/S0304-4017(99)00092-8

-Mahboob K, Khan JA, Khan MS (2008). Prevalence, chemotherapy and haematology of strongylosis in horses of district layyah. J. Anim. P1. Sci. 18 (4): 117-119.

-Mahfooz A, Masood MZ, Yousaf A, Akhtar N, Zafar MA (2008). Prevalence and anthelmintic efficacy of Abamectin against gastrointestinal parasites in horses. Pakistan Vet. J. 28 (2): 76-78.

-Mezgebu T, Tafess K, Tamiru F (2013). Prevalence of gastrointestinal parasites of horses and donkeys in and around Gondar Town, Ethiopia. Open J. Vet. Med. 3 (6): 267-272. https://doi.org/10.4236/ojvm.2013.36043

-Montenaro S, Scala A, Batelli G and Stancamplano L (2002). Epidemiology of gastrointestinal nematode infections in horses in Sardinia. Obiettivi e Documenti Vet. 23: 35-42.

-Morariu S, Oprescu I, Mederle N, Ilie M, Dărăbuș G (2012). Helminth Parasites in horses from five locations of Arad County. Anim. Sci. Biotech. 45(2): 184-187.

- Oli N (2018). Prevalence of gastrointestinal parasites of horses (Equus Caballus Linnaeus, 1758) in Seven village development committee of Rukum district, Nepal. J. Inst. Sci. Tech. 22 (2): 70-75. https://doi.org/10.3126/jist. v22i2.19596

- Radostits OM, Arundel JH, Blood DC, Gay CC (2000). In: Veterinary medicine. 9th ED. W.B.Saunders Company Ltd. London. 1358-1362.

- Rashid A, Khattak MNA, Khan MF, Ayaz S, Rehman A (2016). Gastrointestinal helminthoses: prevalence and associated risk factors in small ruminants of district Kohat, Pakistan. J. Anim. Plant Sci. 26 (4): 956-962.

-Regassa A, Yimer E (2013). Gastro-intestinal parasites of Equine in South Wollo Zone, North Eastern Ethiopia. Glob. Vet. 11(6): 824-830.

- Saeed K, Qadir Z, Ashraf K, Ahmad N (2010). Role of intrinsic and extrinsic epidemiological factors on strongylosis in horses. J. Anim. Plant Sci. 20 (4): 277-280.

- Saleem A, Pervez K, Khan MS, Hashmi HA (2000). Prevalence and chemotherapy of Strongylosis and its effect on various blood Parameters in horse. Pak. J. Sci. 52 (3-4): 41-43.

-Sawsan M, Imam HT, Seri H, Hidaia BZ (2008). Field investigation of gastrointestinal nematodes in horses and donkeys in South Darfur State, Sudan. In: Proceedings of the $13^{\text {th }}$ scientific congress. 723-729.

- Scala A, Batelli G, Stancamplano L, Montenaro S (2002). Epidemiology of the emission of gastrointestinal nematode eggs in horses in Sardinia. 23 (11): 35-42.

- Seri H, Hassan T, Salih M, Abakar A (2004). A Survey of Gastrointestinal Nematodes of Donkeys (Equus asinus) in Khartoum State, Sudan. J. Anim. Vet. Adv. 3 (11): 736-739.

-Sheferaw D, Alemu M (2015). Epidemiological study of gastrointestinal helminths of equines in Damot-Gale district, Wolaita zone, Ethiopia. J. Parasit. Dis. 39 (2): 315320. https://doi.org/10.1007/s12639-013-0352-z

- Soulsby EJL (1984). Helminths, arthropods and protozoa of domesticated animals. In: $7^{\text {th }}$ ED. London: Bailliere Tindall. T. Roy. Soc. Trop. Med. H. 78(3): 329. https://doi. org/10.1016/0035-9203(84)90110-X

- Sonone PV, Srikhande GB, Rode AM, Kolte SW (2013). Haematology of gastrointestinal helminthes affected horses. Ind. J. F. Vet.. 8 (3): 58-59.

- Tahir U, Sajid M, Khan M, Saqib M, Siddique R, Qudoos A (2016). Passive surveillance and risk analysis of 
gastrointestinal parasitism in equine population of Faisalabad metropolitan, Pakistan. J. Anim. Plant. Sci. 26(2): 395-400.

-Tesfu N, Asrade B, Abebe R, Kasaye S (2014). Prevalence and risk factors of gastrointestinal nematode parasites of horse and donkeys in hawassa town, Ethiopia. J. Vet. Sci. Tech. 5 (5).

- Teuscher E (1965). A new single method of examining feces for the diagnosis of helminth diseases of ruminants. Zent. für. Vet. Reihe. B. 12 (3): 241-249.

- Uslu U, Guclu F (2007). Prevalence of endoparasites in horses and donkeys in Turkey. Bull. Vet. Inst. Pul. 51 (2): 237-240.

-Wasti SE, Hanif S, Asif M et al., (2018-19). Pakistan economic survey. Economic advisor's wing, finance division,

\section{Government of Pakistan, Islamabad. 27}

-Worku S, Afera B (2012). Prevalence of equine nematodes in and around Kombolcha South Wollo, Ethiopia. Rev. Elect. Vet. 13: 1-13.

-Wosu MI, Udobi SO (2014). Prevalence of gastrointestinal helminths of horses (Equus caballus) in the southern guinea savannah zone of northern Nigeria.J. Vet. Adv. 4(4): 499-502. https://doi.org/10.5455/jva.20141216110809

- Yadar KS, Shukla PC, Gupta DK, Mishra A (2014). Prevalence of gastrointestinal nematodes in horses of Jabalpur region. Res. J. Vet. Pract. 2 (3): 44-48. https://doi.org/10.14737/ journal.rjvp/2014/2.3.44.48

-Zajac AM, Conboy GA (2012). In: Veterinary clinical Parasitology. $8^{\text {th }}$ ED. Wiley-Blackwell. 187. 